\title{
Agnieszka Szplit
}

Uniwersytet Jana Kochanowskiego w Kielcach

\section{Strategie badania praktyki przez nauczycieli akademickich jako wyraz uczenia się nieformalnego}

\author{
Teacher Educators' Strategies for Research on Practice as \\ a Form of Informal Learning
}

Streszczenie. Podejmowane przez nauczycieli akademickich działania skierowane na poznawanie i doskonalenie własnej praktyki są wyrazem ich nieformalnego uczenia się. Autorka próbuje określić kierunki aktywności badawczej nauczycieli akademickich, którzy kształcą przyszłych nauczycieli. Dokonuje ich przeglądu w oparciu o analizę literatury międzynarodowej. Odnajduje cztery strategie zmierzające do uczenia się poprzez poszukiwania badawcze dotyczące własnej praktyki dydaktycznej: strategię opisu, strategię wzbogacania rzemiosła, strategię ewaluacji oraz strategię współpracy.

Słowa kluczowe: nauczyciel akademicki, uczenie się nieformalne, badania międzynarodowe, strategie badania własnej praktyki

Summary. Teacher educators' actions aimed at learning and improving their own practice are the forms of informal learning. The author describes the directions of practitioners' research on the basis of literature review (80 professional papers). She finds four researchbased learning strategies of teacher educators: describing practice, practice improvement, practice evaluation, and cooperative learning.

Key words: academic teachers, teacher educators, informal learning, international perspective, research-based learning strategies

We współczesnej literaturze poświęconej nauczycielom akademickim kształcącym przyszłych nauczycieli (teacher educators) odnaleźć można wiele informacji o czynnikach wpływających na proces ich uczenia się. Rozwój kadry akademickiej warunkowany jest zarówno stawianymi przed nią zadaniami 
zgodnymi z systemem oceny na uczelni, jak też własną potrzebą udoskonalania samego siebie. Profesjonalizm nauczyciela akademickiego, tak jak i każdego innego, oznacza bowiem angażowanie się w aktywne poszukiwania rozwiązań i dokonywanie refleksji w, nad i o działaniu (Day 2008). Jak stwierdził Richard J. Reynolds nauczyciel akademicki „służy dwóm panom: profesji nauczyciela i społeczeństwu akademickiemu" (1995, s. 222). Odbywa się to poprzez prowadzenie badań naukowych, uznawane przez wielu autorów za konieczny warunek rozwoju zawodowego nauczyciela i doskonalenia systemu kształcenia nauczycieli (Murray 2008; Cochran-Smith \& Lytle,2009; Klecka i in. 2008). John Loughran określa rozwój zawodowy nauczycieli nauczycieli nawet mianem „podróży badawczej” (2014, s. 2). Autor podkreśla, że nauczyciel angażuje się w badania, aby wzbogacać swoją wiedzę na temat uczących się, własnej praktyki dydaktycznej i kształcenia nauczycieli w ogóle. Dzięki poznawaniu własnych działań nauczyciel staje się lepszym dydaktykiem, a prowadzone badania wspomagają jego praktykę (Cochran-Smith 2005; Loughran i Berry 2005). Nauczyciele różnią się jednak podejściem do prowadzenia badań poświęconych praktyce akademickiej (Lunenberg i in. 2014). Zależy to zarówno od wartościowania badań w określonej społeczności akademickiej, wcześniejszych doświadczeń nauczyciela czy też jego indywidualnych predyspozycji.

\section{Postawa badawcza nauczyciela akademickiego}

Zdaniem Hanne Tack i Ruben Vanderlinde (2014) podstawowym czynnikiem wpływającym na prowadzenie badań przez nauczyciela akademickiego są jego predyspozycje badawcze, czyli tendencje do angażowania się w badania. Autorzy rozróżniają trzy aspekty je opisujące: (1) aspekt afektywny, czyli zainteresowanie prowadzeniem badań (inclination) oparte na własnej ocenie ich wartości i zrozumieniu roli zawodowej; (2) aspekt poznawczy, czyli umiejętność prowadzenia badań (ability), związana z wiedzą metodologiczną; (3) aspekt behawioralny, czyli zdolność zauważenia możliwości badawczych (sensitivity). W zależności od podejścia badawczego, a więc obecności wspominanych cech, Tack i Vanderlinde (2014) opisali trzy typy nauczycieli akademickich prowadzących kształcenie nauczycieli. Pierwszy z nich to nauczyciel dociekliwy (the enquiring teacher educator), który ma inklinacje do prowadzenia badań i jest zainteresowany własnym rozwojem, ma też duże doświadczenie w nauczaniu. Poddaje krytycznej analizie swoje działania, lecz nie prowadzi badań o charakterze naukowym ze względu na brak wie- 
dzy metodologicznej oraz brak zainteresowań badawczych. Ze wspominanych aspektów obserwuje się u niego jedynie obecność pierwszego. Drugi typ to tzw. nauczyciel „oczytany” (the well-read teacher educator), czyli posiadający wiedzę metodologiczną i doświadczenie badawcze, który nie prowadzi systematycznych badań, ale korzysta z badań innych osób, stosując ich wyniki w praktyce. Nie zauważa on możliwości badawczych (a więc w jego zachowaniach nie jest widoczny aspekt behawioralny). Ostatni typ nazwany został nauczycielem-badaczem (the teacher educator-researcher), który charakteryzuje się silnie rozwiniętymi predyspozycjami badawczymi, inklinacją i umiejętnościami prowadzenia badań naukowych. Uważa on, że prowadzenie badań jest nieodłączną częścią roli nauczyciela akademickiego i potrafi odnaleźć sytuacje, w których badania wzbogacają jego praktykę (widoczne są wszystkie trzy aspekty działania).

Koncepcję predyspozycji badawczych Tack i Venderlinde odnieść można do pojęcia "gotowości badawczej” (inquiry as stance) (Cochran-Smith, Lytle 2009). Autorki twierdzą, że nauczyciel jest stale gotowy do podejmowania działań jako reakcji na poznawaną wiedzę i informacje płynące z praktyki. Odczuwa on potrzebę zadawania pytań, analizowania i badania rzeczywistości, dzięki czemu zdobywa świadomość, czym jest proces nauczania. Nancy F. Dana (2015) określa trzy składowe komponenty tak rozumianej postawy badawczej nauczyciela. Są to: umiejętność zbierania informacji, integracja roli badacza i nauczyciela oraz potrzeba usprawnienia sytuacji edukacyjnej. Zbieranie danych jest procesem naturalnym, codziennym i odbywa się poprzez obserwację, analizę prac studentów, nagrywanie własnych zajęć, pamiętniki, blogi w sieci, ankiety, pomiar osiągnięć studentów, analizy w grupach z tzw. „krytycznym przyjacielem” i studia nad literaturą. Badania nauczyciela nie są jedynie "projektem” czy zadaniem do wykonania, lecz poszerzeniem działań nauczyciela. Obie role nauczyciela - dydaktyka i badacza - są odgrywane symultanicznie i wzajemnie na siebie oddziałują, efektem działań badawczych jest natomiast polepszenie warunków, w których odbywa się nauczanie. Przejawiane zachowania można nazwać strategiami badawczymi, bowiem, zgodnie z definicją Ewy Czerniawskiej i Marii Ledzińskiej (1986), wymagają aktywności nauczyciela i intencjonalności, są też ukierunkowane na usprawnianie procesu dydaktycznego.

Gotowość nauczycieli akademickich do podejmowania badań dotyczących praktyki akademickiej związana jest z ich motywacją. Jean Murray i Trevor Male (2005) twierdzą, że poziom oczekiwań dotyczących badania własnej praktyki prowadzonych przez nauczycieli akademickich zależny jest głównie od aspiracji naukowych wydziału, na którym pracują nauczy- 
ciele. Tack i Vanderlinde (2015) podają dwa powody, dla których nauczyciele akademiccy angażują się w badania tego typu. Po pierwsze mają na celu usprawnienie własnej praktyki i uzupełnienie wiedzy dotyczącej kształcenia nauczycieli, po drugie pragną wnieść swój wkład w naukę i wiedzę. Autorzy określają także typy zachowań dotyczących prowadzenia badań. Jest to: (1) prowadzenie badań nad dydaktyką akademicką, (2) analiza i ocena badań naukowych dotyczących pracy nauczycieli akademickich oraz (3) inteligentne wykorzystanie wyników badań naukowych w praktyce. W niniejszym artykule ujmuję jednak tylko te badania, które dotyczą własnej praktyki, a więc pierwszego typu zachowań badawczych.

\section{Strategie badania dydaktyki akademickiej przez nauczycieli nauczycieli}

Analizie poddano publikacje dotyczące badań prowadzonych przez nauczycieli nauczycieli, wydane w języku angielskim, w formie rozdziałów w monografiach lub artykułów w wybranych czasopismach naukowych*. Doboru materiału badawczego dokonano zgodnie z metodą kuli śniegowej, dzięki której analiza jednego tekstu poszerzała zakres poszukiwań na kolejne**. Procedura selekcji tesktów (Silvermann 2008) została oparta na słowach kluczowych (motywacja, potrzeby edukacyjne, formy formalnego i nieformalnego rozwoju zawodowego, korzyści, samokształcenie). Pierwotnie poszukiwania dotyczyły tekstów dotyczących rozwoju zawodowego nauczycieli akademickich, kolejno - tylko nauczycieli nauczycieli (79 publikacji), a ostatecznie zbiór stanowią prace poświęcone badaniom dydaktyki akademickiej (38 tekstów). Pojęciem kluczowym jest angielski termin teacher's inquiry. Dodatkowym ograniczeniem był rok wydania (2000-2017). Już analiza pierwszych kilku tekstów narzuciła zastosowaną kategoryzację - prezentowaną poniżej typologię strategii badania praktyki, przy czym odrzucone zostały wszystkie publikacje, które wpisywały się w więcej niż jedną strate-

* M.in.: „Action Research in Education”, „Educational Researcher”, „European Journal of Teacher Education”, „Innovation in Education and Teaching International”, „Journal of Teacher Education”, „Teaching and Teacher Education”, „The New Educator” itp.

** Początkiem były studia nad czasopismem „European Journal of Teacher Education”, wydawanym przez stowarzyszenie The Association for Teacher Education in Europe (ATEE). Wybór czasopisma wynikał z mojego udziału w spotkaniach naukowych stowarzyszenia ATEE i prac wydzielonej w nim grupy badawczej prowadzącej analizy porównawcze rozwoju zawodowego nauczycieli akademickich (Research and Development Community Professional Development of Teacher Educators) w latach 2014-2017. 
gię (kategorie wzajemnie wykluczają się). Poszukiwania kolejnych publikacji zakończone zostały ze względów czasowych, bowiem nasycenie wybranych kategorii nie jest możliwe. Dalsze studia nad literaturą z pewnością przyniosłyby mnóstwo kolejnych przykładów opisujących badania w ramach wyróżnionych strategii.

Zebrane materiały zostały poddane analizie treści w jej jakościowym wymiarze, przy założeniu, że powtarzają się w nich „względnie stałe zespoły i konfiguracje elementów, ideologiczne konstrukcje, dyskursy, opisujące różne aspekty funkcjonowania rzeczywistości” (Lisowska-Madziarz 2004, s. 53). Teksty analizowane były pod kątem istnienia tylko jednego wymiaru zwanego „wymiarem istnienia” (Gerbner 1973, za: Nasalska 1982), a zatem istotna była jedynie obecność określonych zagadnień w wybranych publikacjach.

Pierwszym zastosowanym kryterium analizy zgromadzonego materiału był cel badań opisanych w publikacji. Wyróżnione zostały dwa cele: teoretyczny, zmierzający do wzbogacenia wiedzy nauczycieli akademickich oraz praktyczny, który odnosił się do efektów dydaktycznych, a zatem usprawnienia praktyki. Wartość wiedzotwórczą przypisałam jednej strategii - opisowi działań nauczycieli. Kryterium drugie spełniały natomiast trzy pozostałe grupy tekstów, przy czym efekty opisanych badań miały różny charakter: indywidualny, grupowy i „systemowy”. Korzyści z badań wpływały bowiem na proces uczenia się pojedynczych nauczycieli akademickich i nauczycieli w grupach lub wzbogacały praktykę w większych społecznościach (nauczycieli, studentów, procesu kształcenia na uczelni). W oparciu o wskazane kryteria określiłam opisane poniżej cztery dominujące strategie nauczycieli nauczycieli mające na celu wspomaganie ich uczenia się w toku działania: (1) strategia opisu praktyki dydaktycznej (6 tekstów), (2) wzbogacania rzemiosła (11 tekstów), (3) współpracy (12 tekstów) oraz (4) ewaluacji (9 tekstów). Poniższy tekst ma charakter egzemplifikacyjny, stąd przytaczam wybrane publikacje potwierdzające moje refleksje, nie podając pełnej listy analizowanych tekstów.

\section{Strategia opisu}

Efektem podejmowanych badań jest opis zarówno procesu dydaktycznego w kształceniu akademickim, jak i wybranych aspektów rozwoju zawodowego nauczycieli w miejscu pracy. Są to badania ilościowe lub jakościowe wzbogacające wiedzę teoretyczną, prowadzące do swoistych uogólnień. Przykła- 
dy takich badań to publikacje dotyczące np. wpływu różnych doświadczeń na rozumienie roli zawodowej (Snow, Martin 2014), wielowymiarowego charakteru tożsamości i procesu jej kształtowania w efekcie pracy dydaktycznej (Klecka i in. 2008) czy roli emocji w nauczaniu akademickim (Day, Leitch 2001).

Strategia opisywania procesu dydaktycznego poszerza wiedzę nauczycieli akademickich, wskazując im mniej znane lub nowe obszary pracy akademickiej. Stanowi podstawę, która może, w toku adaptacji do własnych potrzeb, skutkować zarówno usprawnieniem własnych działań dydaktycznych, jak też pobudzać do prowadzenia badań naukowych. Może więc mieć także bezpośrednie przełożenie na kolejną sferę pracy nauczyciela akademickiego, jaką jest praca naukowa. Strategia ta jest jednak dość mało reprezentowana w analizowanej literaturze anglojęzycznej*, dominują w niej bowiem publikacje odnoszące się bezpośrednio do określonych aspektów dydaktyki lub procesu jej organizowania. Są to kolejne trzy strategie.

\section{Strategia wzbogacania rzemiosła}

Celem badań prowadzonych przez nauczycieli akademickich jest dostarczenie wiedzy dotyczącej ich własnej praktyki i dokonywanie zmian w oparciu o nią (Baumfield, Hall i Wall 2013). Strategia wzbogacania rzemiosła to charakterystyczny trend $\mathrm{w}$ badaniach pedagogicznych, których zadaniem jest określenie skuteczności metod, technik czy zachowań nauczycieli w celu wprowadzenia rzeczywistych zmian w praktyce dydaktycznej. Jest to wyraz swoistego utylitaryzmu w podejściu do badań edukacyjnych, w których użyteczność i efektywność są najważniejszymi aspektami procesu dydaktycznego. Stąd badania pedagogiczne, prowadzone przez nauczycieli akademickich zarówno na uczelniach, jak i poza nimi, mają za zadanie określić, jak osiągnąć wspomnianą skuteczność, a niekiedy nawet podać gotowe rozwiązania dydaktyczne. Przykładem takich badań jest szeroko zakrojony projekt ${ }^{* *}$ realizowany przez Johna Hattie z Uniwersytetu w Auckland i Melbourne (2009) dotyczący strategii nauczania i określenia ich skuteczności podczas zajęć (Hattie, Timperley 2007) również na wyższej uczelni (Hattie 2015; Lloyd, Trangmar 2012).

* Publikacje o charakterze opisowym i teoretyczne analizy zachowań nauczycieli akademickich są natomiast bardzo popularne w Polsce (Szplit, 2017).

** Autor dokonał syntezy wyników ponad 900 badań obejmujących miliony uczniów i opublikował je w kilku książkach. 
Kolejnym przykładem strategii badawczej zmierzającej do udoskonalenia praktyki są działania Centrum Innowacji i Rozwoju Edukacji (CESI$\mathrm{RE}$ ) prowadzone przez uniwersytet w Katalonii i uniwersytet w Barcelonie dotyczące metody integracji języka i edukacji przedmiotowej (Coral, Llexia 2017). Bardzo popularnym tematem analizowanym przez nauczycieli akademickich jest wykorzystanie przez nich nowoczesnych technologii (np. Huang, Hood i Yoo 2014), a także sieci społecznościowych (Balakrishnan 2014) czy serwisu internetowego Wiki w celu wspierania kształcenia akademickiego (Cilliers 2017).

Wartością publikacji o takiej tematyce jest dokładny opis procedur zapewniających wysoką skuteczność nauczania i efektów dydaktycznych uzyskanych dzięki nim. Badania te mają charakter informacyjny, są źródłem wiedzy dla osób planujących wprowadzenie innowacji pedagogicznych i nowoczesnych środków dydaktycznych. W ten sposób wspomagają one uczenie się nauczycieli akademickich, pozwalając na usprawnienie lub udoskonalenie ich warsztatu pracy.

\section{Strategia współpracy}

Założeniem współpracy badawczej jest „deprywatyzacja” praktyki w taki sposób, aby refleksja oraz działania usprawniające proces dydaktyczny stały się dobrem wspólnym i przynosiły korzyści w postaci rozwoju wiedzy kolektywnej (Philpott 2016). Uzyskana wiedza jest zatem „wypracowana” w grupie, oparta na doświadczeniu w określonym kontekście i czasie. Strategia ta nawiązuje do działań podejmowanych $\mathrm{w}$ ramach wspólnoty praktyków (Wenger 1998) - w tzw. grupach rozwoju (Professional Learning Communities - PLCs, Philpott 2016) lub formalnych partnerstwach jak Szkoły Rozwoju Zawodowego (Professional Development Schools - PDS, Lillejord, Borte 2016), profesjonalnych kulturach uczenia się (Day 2008), modelach klinicznych, sieciach współpracy (Mtika, Robson, Fitzpatrick 2014) czy jako partnerstwo badawczo-dydaktyczne (Coburn, Penuel 2016). Carey Philpott (2016) stwierdza, że sami nauczyciele w najlepszy sposób pobudzają do rozwoju innych nauczycieli, a zastosowanie wiedzy nauczonej w procesie edukacji akademickiej nie ma odniesienia do praktyki i wymaga jej „przełożenia” na rzeczywistość. Odbywa się to poprzez obserwowanie kolegów, wymianę doświadczeń czy wspólne rozwiązywanie problemów, a w rezultacie pozwala na opracowanie zestawu dobrych praktyk i stworzenie nowych strategii dydaktycznych we własnej modyfikowanej, wspólnej „przestrzeni” (Margo- 
lin 2011). Wiedza kolektywna wzbogaca więc praktykę indywidualnego nauczyciela i przynosi rzeczywiste korzyści w postaci usprawnienia edukacji.

Bardzo popularnym motywem pojawiającym się w badaniach o charakterze analizy działania określonych grup jest opis współpracy szkół i uniwersytetów w ramach kształcenia nauczycieli (Postholm 2016). Przykładem zastosowania takiej strategii badawczej są działania opisane przez Karimę Kadi-Hanifi i jej współpracowników (2014) na uniwersytecie w Worcester. Ich celem było ulepszenie procesu integrowania studentów i kadry akademickiej poprzez tzw. podejście doceniające (appreciative inquiry). Zastosowana metoda składała się z czterech faz: odkrycie (discovery), marzenia (dream), projekt (design) i przeznaczenie (destiny). W pierwszej studenci i pracownicy Instytutu Edukacji przedstawiali własne, pozytywne doświadczenia z bycia we wspólnocie akademickiej, kolejno dzielili się swoimi wizjami wspólnoty idealnej, opracowywali wspólnie propozycje dalszego polepszania pracy grupowej i podejmowali działania mające na celu wdrożenie ich.

Badania prowadzone w zespołach wzbogacają wiedzę uczestników i pozwalają na udoskonalenie praktyki akademickiej. Uczenie się nauczyciela akademickiego odbywa się jednak w szerszym zakresie. Dotyczy bowiem nie tylko samego „rzemiosła” i kompetencji dydaktycznych, lecz pozwala w znacznym stopniu na rozwój jego kompetencji społecznych i komunikacyjnych.

\section{Strategia ewaluacji}

Strategia ta pozwala nauczycielom akademickim analizować doświadczenia związane $\mathrm{z}$ wybranym przedmiotem akademickim w celu modyfikowania jego programu lub sposobu realizacji. Ma zatem cel praktyczny i pozwala na udoskonalenie praktyki. Zauważalne są dwa kierunki, w których zmierzają badania o charakterze ewaluacyjnym. Po pierwsze nauczyciele akademiccy dokonują oceny programów nauczania i efektywności kształcenia, po drugie dokonują określonych zmian w programach kursów, wprowadzają innowacje dydaktyczne i określają ich efekty. Przykładami badań pierwszego typu jest analiza skuteczności aktywnego uczenia się jako metody rozwoju kompetencji nauczycieli (Niemi, Nevgi i Aksit 2016) lub ocena przygotowania studentów do prowadzenia edukacji środowiskowej w szkołach (Miles, Cutter-Mackenzie, Harrison 2014). Badania drugiego typu to np. eksperyment pedagogiczny, w którym zastosowano, jak podają autorzy, strategię złożoności (complexity-based strategy) w nauczaniu akademickim. Polega ona na 
nauczaniu poprzez kompleksowe rozwiazywanie złożonego problemu dydaktycznego, np. opracowanie przez studentów gry dydaktycznej prowadzonej na zlecenie muzeum (Fabricatore, Lopez 2014). Ciekawą innowacją dydaktyczną jest także wykorzystanie lalek w nauczaniu statystyki (Steward, Steward 2014). Celem prowadzenia badań ewaluacyjnych jest określenie, czy innowacje poprawiają efektywność nauczania i czy mogą zostać wprowadzone na stałe do zestawu metod nauczania. W efekcie działań praktycznych i badań je ewaluujących nauczyciel akademicki nie tylko udoskonala swój warsztat pracy, lecz rozwija także wiedzę dotyczącą metodyki nauczania własnego przedmiotu.

Zweryfikowana skuteczność nowych praktyk i działań innowacyjnych w sposób bezpośredni wpływa na rozwój nauczyciela akademickiego. W opisywanych badaniach obserwuje się wyraźne zainteresowanie określonymi innowacjami w celu wprowadzenia ich do własnego repertuaru dydaktycznego. Widoczne jest również silne przekonanie nauczycieli prowadzących badania, iż rozbudowanie własnego warsztatu dydaktycznego wymaga naukowej weryfikacji skuteczności planowanych działań. Świadczy to o silnym poczuciu odpowiedzialności nauczycieli.

\section{Zakończenie}

Podejmowane przez nauczycieli nauczycieli działania badawcze są obrazem ich nieformalnego uczenia się. Odnosząc się do definicji Mieczysława Malewskiego (2010) stwierdzić można, że proces uczenia się nauczycieli akademickich odbywa się w sytuacji codziennej, nawiązuje do określonych sytuacji problemowych pojawiających się w danym kontekście kulturowym oraz dotyczy wszystkich uczestników. Prowadzone badania, niezależnie od przyjętej strategii, pozwalają nauczycielom z jednej strony na poszerzenie wiedzy, z drugiej na ulepszanie procesu nauczania. Mają też zasadnicze znaczenie w ich rozwoju zawodowym (Tillema, Kremer-Hayoun 2002).

Uczenie się nieformalne nauczyciela wymaga refleksji i własnej aktywności, opiera się na zdobywaniu wiedzy, jej weryfikowaniu i wykorzystaniu (Day 2008). Analizowane strategie badania praktyki akademickiej przynoszą różnorodne efekty. Strategia opisu skutkuje przede wszystkim poszerzeniem wiedzy nauczycieli i w stosunkowo niewielkim stopniu dotyczy działań praktycznych. Pobudza jednak wiele obszarów zainteresowań nauczycieli nauczycieli, w tym badawczych, $\mathrm{z}$ racji prowadzenia przez nich często badań interdyscyplinarnych (głównie połączenia pedagogiki i psychologii). Kolej- 
ne strategie odnoszą się do rozwoju kompetencji nauczyciela poprzez udoskonalanie rzemiosła i ewaluację działań praktycznych. Dwie wspomniane strategie odnoszą się do rozwoju zawodowego nauczyciela i zmian w zakresie jego osobistych działań dydaktycznych. Strategia współpracy natomiast poszerza zakres procesu uczenia się, umożliwiając nie tylko rozwój kompetencji dydaktycznych, ale także zmiany w zakresie relacji interpersonalnych i kompetencji społecznych. Stwierdzić zatem można, że rozwój nauczyciela nauczycieli na skutek prowadzenia badań praktyki akademickiej jest wielokierunkowy i często wykracza poza sferę samej tylko dydaktyki.

W zależności od predyspozycji i podejścia do praktyki nauczyciele nauczycieli podejmują się zróżnicowanych działań, korzystając z własnych, osobistych strategii badawczych. Efektem tych prac jest opis rzeczywistości akademickiej, który pozwala na lepsze zrozumienie procesu kształcenia akademickiego oraz wzbogaca nauczycieli o szczegółowe informacje o skutecznych sposobach nauczania. Poza rolą informacyjną i wiedzotwórczą badania nauczycieli akademickich pozwalają na określenie skuteczności zastosowania innowacyjnych metod w kształceniu nauczycieli i udoskonalenie procesu nauczania. Badania prowadzone przez nauczycieli akademickich zapewniają nie tylko dostęp do rzeczywistej, nieodrealnionej wiedzy, ale i pozwalają na wykorzystanie jej w praktyce. Zapewniają zatem najlepsze warunki uczenia się w miejscu pracy.

\section{Bibliografia}

Balakrishnan V. (2014), Using social networks to enhance teaching and learning experience in higher learning institutions, „Innovation in Education and Teaching International", 6(51), s. 595-606.

Baumfield V., Hall E. \& Wall, K. (2013), Action Research in Education, Sage, London.

Cilliers L. (2017), Wiki acceptance by university students to improve collaboration in higher education, „Innovation in Education and Teaching International”, 9(54), s. 485-493.

Coburn C.E., Penuel W.R. (2016), Research - practice Partnership in Education: Outcomes, Dynamics, and Open Questions, „Educational Researcher”, 1(45), s. 48-54.

Cochran-Smith M. (2005), Teacher educators as researchers: multiple perspectives, „Teaching and Teacher Education”, 21(2), s. 219-225.

Cochran-Smith M., Lytle S.L. (2009), Inquiry as Stance: Practitioner Research for the Next Generation, Teachers College Press, New York. 
Coral J., Llexia T. (2017), In-service Content and Language Integrated Learning (CLIL) teacher development: An Action Research project in teachers' professional learning, [w:] Boyd P., Szplit A. (red.), Teachers and Teacher Educators Learning through Inquiry: International Perspectives, Attyka, Kielce-Kraków.

Czerniawska E., Ledzińska M. (1986), Ontogeniczny rozwój strategii pamięciowych i ich ćwiczenie, [w:] Włodarski Z., Psychologiczne problemy pamięci, PWN, Warszawa.

Dana N. F. (2015), Understanding Inquiry as Stance: Illustration and Analysis of One Teacher Researcher's Work, „LEARNing Landscapes”, 8(2), s. 161-171.

Day C., Leitch R. (2001), Teachers' and teacher educators' lives: The role of emotion, „Teaching and Teacher Education”, 17, s. 403-415.

Day Ch. (2008), Od teorii do praktyki. Rozwój zawodowy nauczyciela, Gdańskie Wydawnictwo Psychologiczne, Gdańsk.

Fabricatore C.; Lopez M.X. (2014), Complexity-based learning and teaching: a case study in higher education, „Innovation in Education and Teaching International”, 6(51), s. 618-630.

Hattie J.; Timperley, H. (2007), The Power of Feedback, „Review of Educational Research", 77(1), s. 81-112.

Hattie J. (2009), Visible learning: A Synthesis of 800+ meta-analyses on achievement, Routledge, London.

Hattie J. (2015), The Applicability of Visible Learning to Higher Education, „Scholarship on Teaching and Learning Psychology", 1(1), s. 79-91.

Huang W.D., Hood D. W., Yoo S.J. (2014), Motivational suport inWeb 2.0 learning environments: a regression analysis based on the integrative theory of motivation, volition and performance, „Innovation in Education and Teaching International”, 6(51), s. 631-641.

Kadi-Hanifi K., Dagman O., Peters J., Snell E., Tutton C., Wright T. (2014), Engaging students and Staff with educational development through appreciative inquiry, „Innovation in Education and Teaching International”, 6(51), s. 584-594.

Klecka C., Donovan L., Venditti K. \& Short, B. (2008), Who is a teacher educator? Enactment of teacher educator identity through electronic portfolio development, „Action in Teacher Education”, 29(4), s. 83-91.

Lillejord S., Borte K. (2016), Partnership in teacher education - a research mapping, „European Journal of Teacher Education”, 4(39), s. 550-563.

Lisowka-Madziarz M. (2004), Analiza zawartości mediów. Przewodnik dla studentów, Uniwersytet Jagielloński, Kraków.

Lloyd C., Trangmar R. (2012), Investigating the Implications of Hattie's. Synthesis of Meta-Analyses for Teaching Higher Education in Further Education, „Teacher Education Network Journal", 4(3), s. 59-76.

Loughran J. (2014), Professionally developing as a teacher educator, „Journal of Teacher Education", 65(4), s. 1-13.

Loughran J., Berry A. (2005), Modelling by teacher educators, „Teaching and Teacher Education", 21(2), s. 193-203. 
Lunenberg M., Dengerink J., Korthagen F. (2014), The professional teacher educator: Professional roles, behaviour and development of teacher educators, Sense Publishers, Boston.

Malewski M. (2010), Od nauczania do uczenia się. O paradygmatycznej zmianie w andragogice, Dolnośląska Szkoła Wyższa, Wrocław.

Margolin I. (2011), Professional Development of Teacher Educators through a „Transitional Space”: A Surprising Outcome of a Teacher Education Program, „Teacher Education Quarterly", 3, s. 7-25.

Miles R., Cutter-Mackenzie A., Harrison L. (2014), Teacher Education: A Diluted Environmental Education Experience, [w:] Boyd P., Szplit A., Zbróg Z. (red.), Teacher Educators and Teachers as Learners, Libron, Kraków.

Mtika P., Robson D., Fitzpatrick R. (2014), Joint Observation of Student Teaching and Related Tripartite Dialogue during Field Experience: Partner Perspectives, „Teaching and Teacher Education", 39, s. 66-76.

Murray J., Male T. (2005), Becoming a teacher educator: evidence from the field, „Teaching and Teacher Education", 21, s. 125-142.

Murray J. (2008), Teacher educators' induction into higher education: work-based learning in the micro communities of teacher education, „European Journal of Teacher Education", 31(2), s. 117-133.

Nasalska E. (1982), Kierunki rozwoju analizy treści, „Studia Socjologiczne”, 3-4, s. $51-67$.

Niemi H., Nevgi A., Aksit F. (2016), Active learning promoting student teachers' professional competence in Finland and Turkey, „European Journal of Teacher Education", 4(39), s. 471- 490.

Philpott C., Oates C. (2016), Teacher Agency and Professional Learning Communities; what can Learning Rounds in Scotland teach us?, „Professional Development in Education", DOI:10.1080/19415257.2016.1180316

Postholm M.B. (2016), Collaboration between teacher educators and schools to enhance development, „European Journal of Teacher Education”, 4(39), s. 452-470.

Reynolds R.J. (1995), The professional self-esteem of teacher educators, „Journal of Teacher Education", 46(3), s. 216-227.

Silverman D. (2008), Prowadzenie badań jakościowych, Wydawnictwo Naukowe PWN, Warszawa.

Snow J.L., Martin S.M. (2014), Confessions of Practice: Multidimensional Interweavings of Our Work as Teacher Educators, „The New Educator”, 4(10), s. 331-353 .

Steward S., Steward W. (2014), Teaching Bayesian statictics to undergraduate students through debates, „Innovation in Education and Teaching International”, 6(51), s. 653-663.

Szplit A. (2017), Inquiry-based Continuing Professional Development for University Teachers: Polish Initiatives and Concerns, [w:] P. Boyd, A. Szplit. Teachers and Teacher Educators Learning Through Inquiry: International Perspectives, Attyka, Kraków-Kielce. 
Tack H., Vanderlinde R. (2014), Teacher Educators' Professional Development: Towards a Typology of Teacher Educators' Researcherly Disposition, „British Journal of Educational Studies: New Directions in Teacher Education”, 62(3), s. 297-315 .

Tillema H.H., Kremer-Hayon L. (2002), 'Practising What We Preach' - Teacher Educators' Dilemmas in Promoting Self-regulated Learning: a Cross-case Comparison, „Teaching and Teacher Education”, 18, s. 593-607.

Wenger E. (1998), Communities of Practice: Learning, Meaning, and Identity, Cambridge University Press, Cambridge.

\section{Netografia}

Tack H., Vanderlinde R. (2015), Teacher Educators' Professional Development: The Development of a Researcherly Disposition, Annual Meeting of the American Educational Research Association, Abstracts. Chicago, dostępny na: http://hdl. handle.net/1854/LU-7004424 (otwarcie wielokrotne 2017). 